\title{
PENENTUAN LOKASI KLINIK LAYANAN HIV/AIDS DI KABUPATEN MALANG DENGAN AHP DAN VISUALISASI GIS
}

\author{
Adithya Gilang Maulana ${ }^{1}$, Dyah Ayu Irawati ${ }^{2}$, Budi Harijanto ${ }^{3}$ \\ Program Studi Teknik Informatika, Jurusan Teknik Elektro, Politeknik Negeri Malang \\ adithsign@gmail.com ${ }^{1}$, dyah.ayu@polinema.ac.id ${ }^{2}$, budi.harijanto@polinema.ac.id ${ }^{3}$
}

\begin{abstract}
Abstrak
Penentuan lokasi klinik untuk pemeriksaan Infeksi Menular Seksual (IMS) merupakan suatu kebutuhan terutama di Kabupaten Malang yang menempati urutan ketiga dalam peringkat HIV/AIDS di Jawa Timur setelah Surabaya dan Kota Malang. Penanggulangan IMS merupakan salah satu langkah awal menanggulangi HIV/AIDS, mengingat tingkat prevalensi seseorang yang terkena IMS adalah mencapai 2-10 kali lipat beresiko terhadap HIV/AIDS. Kabupaten Malang memiliki karakteristik tersendiri yang rawan terhadap keadaan ini seperti banyaknya lokalisasi dan sebagai daerah dengan tingkat pengiriman TKI/TKW terbesar di Jawa Timur. Maka langkah awal membendung penyebaran HIV/AIDS adalah dengan membuka layanan klinik IMS di beberapa tempat di Kabupaten Malang. Permasalahannya, tidak semua kecamatan menyediakan layanan klinik ini. Maka dengan kriteria yang telah ditetapkan, seperti jumlah lokalisasi, ketersediaan fasilitas laboratorium puskesmas, jumlah TKI/TKW, dan jumlah pengguna narkoba suntik pada masing-masing kecamatan di Kabupaten Malang, penentuan layanan klinik IMS ini dilakukan dengan perhitungan metode AHP atau Analytical Hierarchy Process sebagai pendukung keputusan. Nilai kriteria diperoleh dari inputan user untuk menentukan tingkat kepentingan masing-masing kriteria, sedangkan nilai alternatif diperoleh dari data masingmasing kecamatan terhadap kriteria. Perhitungan dilakukan dengan melakukan normalisasi di tingkat kriteria dan tingkat alternatif. Prioritas global diperoleh dengan menjumlahkan hasil perkaliannya. Hasil rekomendasinya akan divisualisasikan ke dalam peta Sistem Informasi Geografi atau GIS sehingga dapat diketahui profil masing-masing kecamatan terhadap kasus ini.
\end{abstract}

Kata kunci : Infeksi Menular Seksual (IMS), Analytical Hierarchy Process, Sistem Informasi Geografi.

\section{Pendahuluan}

Wilayah Kabupaten Malang merupakan salah satu daerah dengan tingkat penderita HIV/AIDS tertinggi di Jawa Timur, dengan menduduki urutan ketiga setelah Surabaya dan Kota Malang. Hal ini semakin memprihatinkan dengan bertambahnya jumlah kasus dari 172 pada tahun 2012 menjadi 221 pada tahun berikutnya. Dinas Kesehatan Kabupaten Malang yang berpusat di Kepanjen, merupakan lembaga yang memiliki otoritas dalam upaya penanggulangan masalah ini. Lebih mengejutkannya lagi bahwa dinas kesehatan melansir sebuah data bahwa dari total jumlah 33 kecamatan yang ada di Kabupaten Malang, hanya ada 1 kecamatan yang terbebas dari paparan HIV/AIDS, ini merupakan data pada tahun 2012.

Komisi Penanggulangan AIDS atau KPA menyatakan bahwa tingkat kerawanan terjangkitnya HIV/AIDS di Kabupaten Malang terbesar adalah dari kelompok tenaga kerja luar negeri atau TKW/TKI. Sementara BNP2TKI atau Badan Nasional Penempatan dan Perlindungan
Tenaga Kerja Indonesia menyatakan bahwa Kabupaten Malang adalah wilayah pengirim TKI terbesar di Jawa Timur. Pada tahun 2013 angka pengiriman TKI dari Kabupaten Malang mencapai lebih dari 5.800 orang atau sekitar $11 \%$ dari total TKI Jawa Timur.

Fenomena HIV/AIDS telah menimbulkan banyak fluktuasi keadaan sosial kemasyarakatan, khususnya di Kabupaten Malang seperti kekhawatiran akan diskriminasi dan dikucilkan. Stigma tersebut membuat Dinas Kesehatan Kabupaten Malang kesulitan dalam memperoleh data yang sebenarnya mengenai profil penderita HIV/AIDS, Dinas Kesehatan menyatakan bahwa telah disediakan fasilitas pemeriksaan terhadap siapapun yang hendak memeriksakan dirinya dan tentu saja dengan identitas yang dijamin kerahasiaannya. Keberadaan klinik IMS atau infeksi menular seksual merupakan salah satu pintu gerbang penanggulangan HIV/AIDS karena seseorang yang terkena IMS lebih besar tingkat kerawanannya terhadap penularan dan penyebaran HIV/AIDS. Klinik layanan ini 
diharapkan dapat menjangkau daerah yang rentan terhadap penyebaran HIV/AIDS, termasuk mempermudah para TKI/TKW yang pulang untuk dapat memeriksakan dirinya melalui klinik ini.

Penentuan lokasi layanan klinik IMS mengacu pada beberapa kriteria yang berpotensi akan munculnya populasi dan kondisi rawan terjangkitnya IMS. Keberadaan klinik IMS akan dimandatkan oleh Dinas Kesehatan Kabupaten Malang kepada kecamatan yang memiliki Puskesmas lengkap dan beberapa kriteria pendukung seperti keberadaan lokalisasi dan panti pijat, keberadaan laboratorium puskesmas, adanya kelompok penasun (pengguna narkoba jarum suntik) atau IDU (Inject Drug User), adanya kelompok TKW/TKI dan jumlah kasus HIV/AIDS per kecamatan yang telah terdata.

Sumber kerumitan dalam pengambilan keputusan bukan hanya karena banyaknya pilihan, namun juga banyaknya kriteria terhadap sebuah permasalahan. Maka dalam penelitian ini penentuan lokasi layanan klinik IMS akan menggunakan metode Sistem Pendukung Keputusan AHP. Hasil perhitungan AHP akan divisualisasikan dengan Sistem Informasi Geografis peta wilayah yang memiliki prioritas berdasarkan peringkat yang dihasilkan dalam perhitungannya.

\section{Teori Dasar}

\subsection{Sistem Informasi Geografi}

Sistem Informasi Geografis (SIG atau dalam bahasa inggris GIS) hingga saat ini, merupakan sistem yang sangat menarik. Sistem yang selalu dibuat untuk interaktif ini dapat mengintergrasikan data spasial, atribut, dan properties penting lainnya. Data spasial dapat berupa citra dijital maupun vektor, sementara data atribut adalah tabel basisdata. (Eddy,2007)

Fungsionalitas milik perangkat lunak SIG yang paling utama selain kempuannya dalam mapping system dan kartografisnya adalah kemampuannya dalam menjawab hal-hal terkait analisis berupaquery. SIG dapat memecahkan masalah-masalah analisis spasial, atribut, dan kombinasinya. Maka dari itu, dengan memanfaatkan SIG , setiap pengguna dapat mengotomasikan proses-proses analisis dan pembuatan peta dijital - yang sebelumnya dilakukan secara manual atau semi otomatissecara cepat, akurat dan dapat diulang secara cermat. Selain itu pada saat ini, mayoritas perangkat lunak SIG juga dilengkapi dengan kemampuan menampilkan dan mengolah data permukaan tiga dimensi berupa data raster grid, DTM/DEM sebagai alat bantu pemodelandengan aspek dimensi ketiga yang tidak kalah pentingnya. (Eddy,2007)

\subsection{Perangkat Lunak SIG Berbasis Internet}

Pada saat ini sudah banyak yang tersedia baik yang komersial maupun yang nonjkomersial, tool atau perangkat lunak yang berfungsi sebagai server penyimpan dokumen peta atau yang biasa disebut map server di dalam aplikasi web maupun sekedar pendukung dalam menampilkan unsur-unsur spasial yang terdapat dalam viewatau lembar kerja perangkat lunak pembangun GIS ke tampilan aplikasi browser internet.

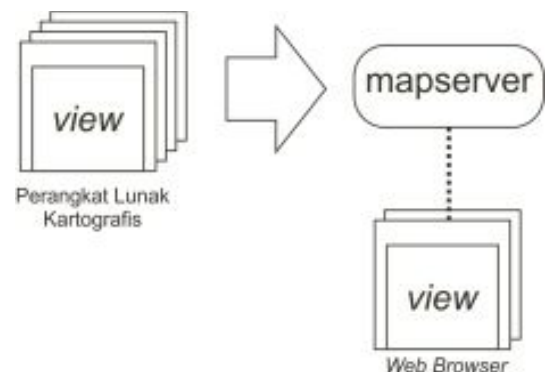

Gambar 2. 1 Penggunaan Mapserver

Perangkat lunak kartografisdengan masing-masing karakternya yang khas diantaranya adalah ArcIMS, MapServer, MapXtreeme, MapObjects IMS, ArcView IMS , Demis, Autodesk MapGuide, GeoMedia WebMap Publisher, Alov Map, CartoWeb, BeyondGeo, ReefBase, Kmap, WorldKit, Stylush Studio XML Mapping Tools, Quest, Geoid, GeoNetWork opensourcedan masih banyak lagi. Pengguna bebas memilih tools ini berserta scripting compiler-nya (untuk membangun server aplikasinya) sesuai dengan kebutuhannya. (Eddy,2007)

Perangkat lunak kartografis yang telah disebutkan diatas sebenarnya merupakan sebuah software yang siap pakai dalam artian telah tersedia fasilitas untuk menggambar peta, digitasi peta dan pemberian atribut spasial.

\subsection{MapServer}

MapSever merupakan (salah satu) lingkungan pengembangan (perangkat lunak) open source yang dapat digunakan untuk mengembangkan aplikasi-aplikasi internet-based yang melibatkan (tampilan) data spasial (peta dijital). MapServer memiliki ukup fungsionalitas inti SIG yang dapat mendukung berbagai aplikasi web yang terkait spasial. Selain itu MapSever juga sangat unggul dalam me-render data spasial (citra, data vektor, dan peta dijital lainnya) untuk aplikasi web.(Eddy,2007)

\subsection{PostgreSQL}

PostgreSQL adalah salah satu sistem perangkat lunak aplikasi basis dara [DBMS] yang bersifat objek-relasional (ORDBMS - objectrelational-DBMS) dan masih memiliki fitur-fitur 
khas DBMS tradisional, tetapi dengan sejumlah perbaikan unjuk-kerja dan fungsional sebagaimana juga bisa ditemukan pada sistem-sistem DBMS generasi pada saat ini. Selain itu, PostgreSQL juga merupakan perangkat lunak yang bersifat free \& opensource. Sebagian sourcecode sistem perangkat lunak DBMS ini pada akhirnya dikembangkan oleh anggota anggota tim/kelompok (komunitas) pengembang yang sebagian besar tersebar di dunia dan tidak dibayar secara khusus (cenderung bersifat volunteer), PosGreSQL Global Development Group. Para anggota tim pengembang ini saling berkomunikasi dan berkorordinasi melaui internet (terutama email) dan menyebut pekerjaan mulia tersebut sebagai "proyek komunitas" yang sama sekali tidak dikendalikan oleh perusahaan (badan hukum komersial) tertentu. (Eddy, 2012)

\subsection{Analitical Hierarchy Process}

Analytical Hierarchy Processpertama kali dikemukan oleh Dr. Thomas L. Saaty dari Wharton School of Business pada tahun 1970. AHP merupakan suatu metode yang digunakan dalam proses pengambilan keputusan suatu masalah masalah kompleks seperti permasalahan: perencanaan, penentuan alternatif, penyusunan prioritas, pemilihan kebijaksanaan, alokasi sumber, penentuan kebutuhan, peramalan kebutuhan, perencanaan performance, optimasi, dan pemecahan konflik (Saaty, 1980). Suatu masalah dikatakan kompleks jika struktur permasalahan tersebut tidak jelas dan tidak tersedianya data dan informasi statistik yang akurat, sehingga input yang digunakan untuk menyelesaikan masalah ini adalah intuisi manusia. Namun intuisi ini harus datang dari orang-orang yang memahami dengan benar masalah yang ingin dipecahkan (orang yang expert).(Arisa,2009)

Secara umum langklah-langkah perhitungan AHP dapat dijelaskan sebagai berikut:

1. Mendefinisikan masalah dan menentukan tujuan/solusi yang diinginkan.

2. Membuat struktur hirarki dari permasalahan secara terstruktur.

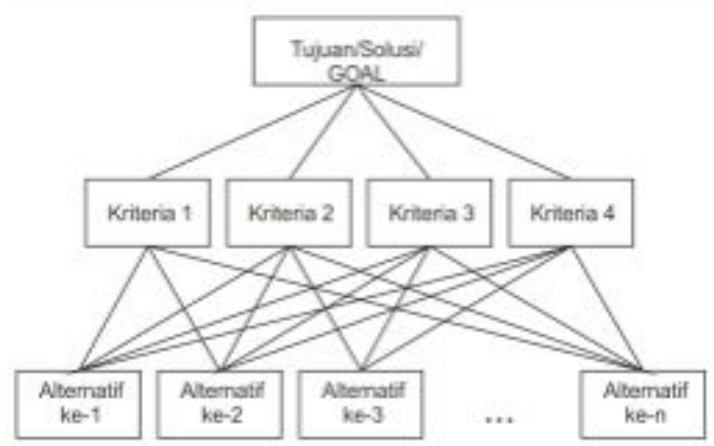

Gambar 2.2 Menyusun permasalahan dalam hirarki

\subsubsection{Model Inputan}

Model inputan dari AHP dapat berupa matriks perbandingan dan nilai riil. Nilai Maksimum yang dimiliki AHP adalah 9 dan nilai minimumnya adalah 1.Berikut macam model inputan serta cara konversi nilai:

\section{a. Perbandingan Matrik}

Model inputan ini adalah dengan membandingkan suatu kriteria dalam matrik dengan kriteria itu sendiri, misalnya sub-kriteria 1 dengan sub-kriteria, maka pada satu sisi diagonal pembanding itu harus bernilai 1 .

Membandingkan sub-kriteria yang pertama (kolom sebelah kiri) dengan sub-kriteria yang kedua (di baris puncak) dan taksir nilai numeriknya dari skala dalam tabel 2.1 berikut:

\begin{tabular}{|l|c|c|c|}
\hline Kriteria & Kriterias 1 & Kriteria 2 & Kriteria 3 \\
\hline Kriteris 1 & 1 & & \\
\hline Kriterias 2 & & 1 & \\
\hline Kriteria 3 & & & t \\
\hline
\end{tabular}

Tabel 2. 1 Model Inputan Matrik Perbandingan

\section{b. Nilai Riil}

Bentuk inputan pada model ini adalah berupa nilai riil dimana nilai ini merupakan nilai satuan, yaitu nilai yang dimiliki AHP mulai dari nilai 1 hingga 9. Hanya saja perbedaannya adalah karena tidak dilakukan perbandingan terhadap kriteria yang lain, maka model inputan ini tidak menerima nilai riil $1 / 2,1 / 3,1 / 4, \ldots, 1 / 9$

Cara mendapatkan perhitungan prioritas lokal adalah sebagai berikut:

Jika inputannya adalah

\begin{tabular}{|l|l|}
\hline Kriteria & Nilai \\
\hline Kriteria 1 & 3 \\
\hline Kriteria2 & 4 \\
\hline Kriteria 3 & 5 \\
\hline tocal & 12 \\
\hline
\end{tabular}

Tabel 2. 2 Model Inputan Nilai Riil

Maka prioritas lokal dapat dihitung dengan membagi semua nilai dalam kriteria itu dengan nilai total atau jumlahnya. Jika pada contoh diatas maka total nilai adalah $(3+4+5=12)$, maka prioritas lokal kriteria 1 adalah $(3 / 12=0.25)$ kriteria 2 adalah $(4 / 12=0.33)$ dan kriteria 3 adalah $(5 / 12=0.42)$. Sehingga akan didapat prioritas lokal sebagai berikut:

\begin{tabular}{|l|l|}
\hline Kriberia & Nilai \\
\hline Kriseria 1 & 0.25 \\
\hline Kriveria 2 & 0.33 \\
\hline Kriveria3 & 0.42 \\
\hline
\end{tabular}

Tabel 2. 3 Hasil Perhitungan Nilai Riil 


\subsection{Metode}

\subsubsection{Rancangan Sistem}

Alur kerja sistem dalam diagram flowchart dimulai dengan start, selanjutnya user akan melakukan input nilai AHP pada kriteria yang ditentukan. Proses inputan ini meminta user untuk mengisikan angka riil setiap kriteria dari tingkat yang terpenting sampai yang tingkat kepentingannya kecil. Lalu user dengan melakukan klik tombol 'hitung', maka sistem otomatis melakukan proses perhitungan AHP yang dalam diagram flowchart pada gambar 4.10 diatas akan dijelaskan dalam sub diagram pada bagian berikutnya. Perhitungan AHP dalam sistem ini akan menghasilkan keputusan berupa rekomendasi kecamatan dari perhitungan AHP untuk selanjutnya akan ditampilkan dalam bentuk peta.

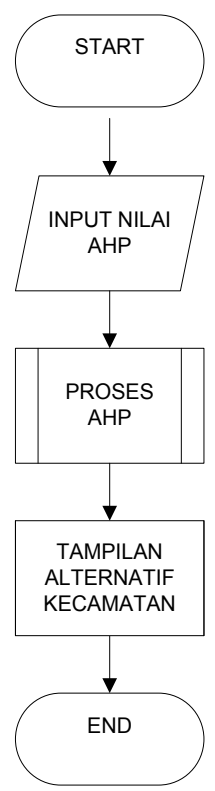

Gambar 2. 3 Flow Chart

\subsubsection{Konfigurasi sistem}

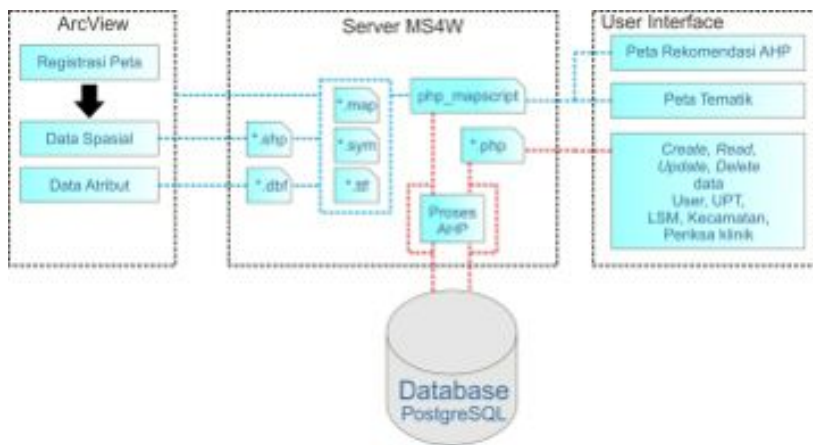

Gambar 2.4Konfigurasi sistem

\section{a. Pre-Processing}

Tahapan ini akan dilakukan proses kartografi pembuatan peta Kabupaten Malang. Proses ini akan dilakukan di perangkat lunak ArcView GIS yang meliputi registrasi peta, pembuatan polygon data spasial, pembuatan table atribut, dan proses export menggunakan ekstensi Gix Export Tool.

\section{b. Persiapan Server dan Database}

Hasil keluaran dari perangkat lunak ArcView GIS diantaranya file penyimpan data spasial (*shp), file penyimpan data tabel atribut (*.dbf), mapfile (*.map), file penyimpan simbol (*.sym) dan file penyimpan font (*.ttf). Selanjutnya semua file itu dikonfigurasi dan akan dimasukkan kedalam server peta. Aplikasi ini menggunakan mapscript untuk menampilkan seluruh petanya.

Entitas utama dalam aplikasi ini akan disimpan menggunakan PostgreSQL meliputi data user, UPT, LSM, kecamatan dan data periksa klinik.

\section{c. Implementasi User Interface}

Tahapan ini adalah proses membuat user interface agar dapat berinteraksi dengan user antara lain manajemen data utama, menampilkan peta rekomendasi hasil perhitungan AHP dan peta tematik menggunakan query.

\section{d. Perancangan AHP}

Pada tahap ini akan membahas tentang pemilihan kriteria yang dibutuhkan untuk menentukan alternatif lokasi layanan klinik IMS di Kabupaten Malang. Berdasarkan hasil wawancara dengan Kepala P2ML Dinas Kesehatan Kabupaten Malang, untuk menentukan lokasi klinik IMS di kecamatan, diperlukan beberapa pertimbangan antara lain:

1. Jumlah kasus HIV/AIDS yang ditemukan.

2. Ketersediaan fasilitas/sarana prasarana laboratorium di puskesmas.

3. Keberadaan Lokalisasi

4. Jumlah panti pijat

5. Jumlah kelompok penasun atau pengguna narkoba jarum suntik.

6. Jumlah TKI/TKW

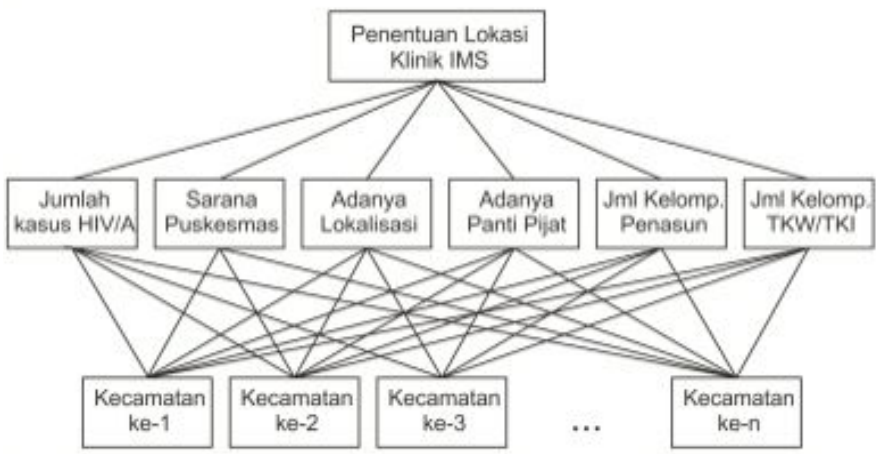

Gambar 2. 5 Susunan Hirarki permasalahan sistem 


\section{Proses perhitungan AHP untuk menentukan alternatif}

Proses inputan untuk memberikan bobot kriteria pada aplikasi ini menggunakan nilai riil yang sesuai dengan jumlah kriteria yakni $1,2,3,4,5$, dan 6. Seluruh inputan ini harus dilakukan oleh user untuk dapat diproses dengan perhitungan metode AHP. Angka 1 sampai 6 tersebut mewakili tingkat kepentingan masing-masing kriteria, atau dapat diterjemahkan kedalam kalimat "prioritas ke-..." maka angka 1 menyatakan tingkat kriteria yang terpenting sampai yang tingkat kepentingannya terkecil dinyatakan dengan angka 6 .

\begin{tabular}{|c|c|}
\hline Angla liputan & Niai ALP \\
\hline 1 & 6 \\
\hline 2 & 5 \\
\hline 3 & 4 \\
\hline 4 & 3 \\
\hline 5 & 2 \\
\hline 6 & 1 \\
\hline
\end{tabular}

Tabel 2. 4 Konversi Prioritas Kriteria

\section{Pembahasan}

Inputan dilakukan oleh user dengan melakukan klik pada menu dropdown berisi pilihan tingkat prioritas dari angka 1 sampai 6. Inputan kali ini memasukkan angka dengan prioritas pertama adalah kritria jumlah kasus, kedua adalah kriteria sarana puskesmas, prioritas ketiga adalah adanya lokalisasi, keempat adalah keberadaan panti pijat, kelima adalah jumlah pengguna narkoba suntik, dan yang keenam adalah jumlah TKI/TKW. Maka sistem akan melakukan konversi kedalam nilai AHP.

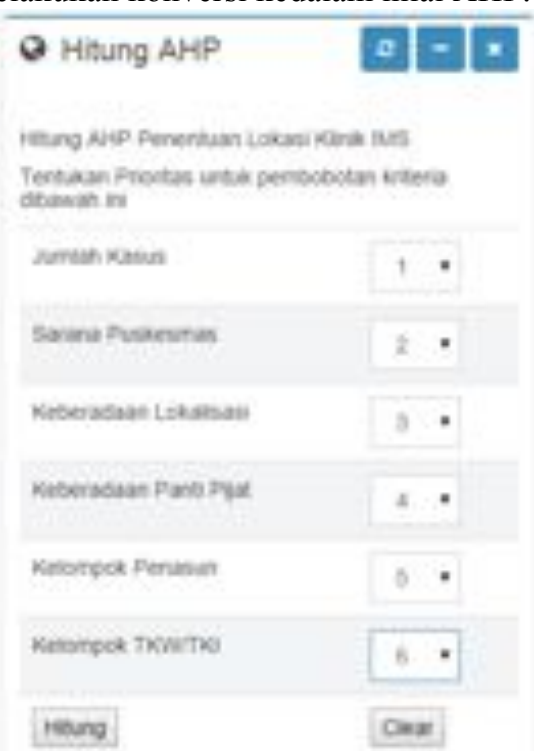

Gambar 3. 1 Form Inputan Nilai Tingkat Kepentingan Kriteria
Inputan pada gambar 3. 1 akan menghasilkan perhitungan sistem seperti pada tabel 2. 5 dimana akan dilakukan normalisasi dengan membagi perolehan nilai dengan total.

\begin{tabular}{|c|c|c|c|}
\hline Kriteris & $\begin{array}{l}\text { Prboritas } \\
\text { An- }\end{array}$ & Nallai & Priaritas Lakal \\
\hline Janlah Kavis & 1 & 6 & $621=0.2557$ \\
\hline Janilab Surnis guskesens & 2 & 5 & $521=0.2350$ \\
\hline Jaสilah Lekalsas & 5 & 4 & $421=0,1904$ \\
\hline Jumlah Pacti Pijat & 4 & 3 & $3 / 21=0,14,3$ \\
\hline Jamlah kelonipok Renuine & 5 & 2 & $221=0,0052$ \\
\hline \multirow{3}{*}{$\begin{array}{l}\text { Jarnlah krlouspok } \\
\text { TKI/TKW }\end{array}$} & 6 & 1 & $\mathrm{t} / 21=0.04 \% 6$ \\
\hline & & & \\
\hline & & 21 & \\
\hline
\end{tabular}

Tabel 2. 5 Form inputan nilai tingkat kepentingan kriteria

Berikut merupakan hasil tampilan aplikasi yang menunjukkan jendela peringkat prioritas kecamatan hasil perhitungan AHP.

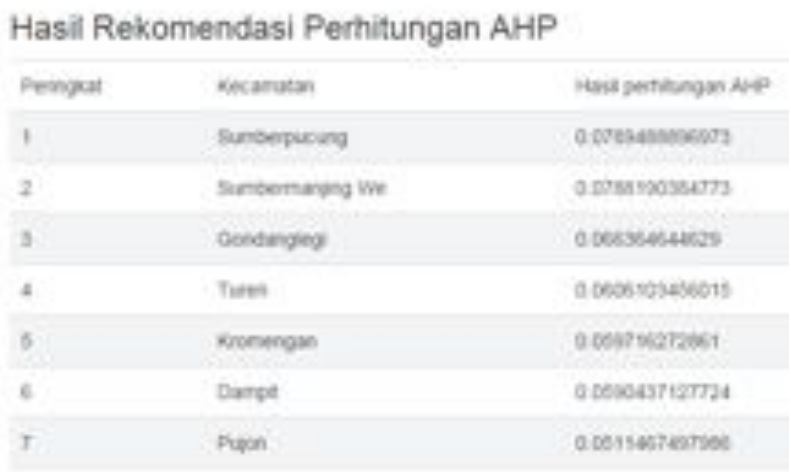

Gambar3. 2 Tampilan urutan alternatif kecamatan berdasarkan perhitungan AHP

Tampilan peta hasil rekomendasi dari perhitungan AHP akan dibagi menjadi dua klasifikasi yang pertama adalah peringkat 1-5 yang titandai dengan warna merah dan peringkat 6-10 yang 


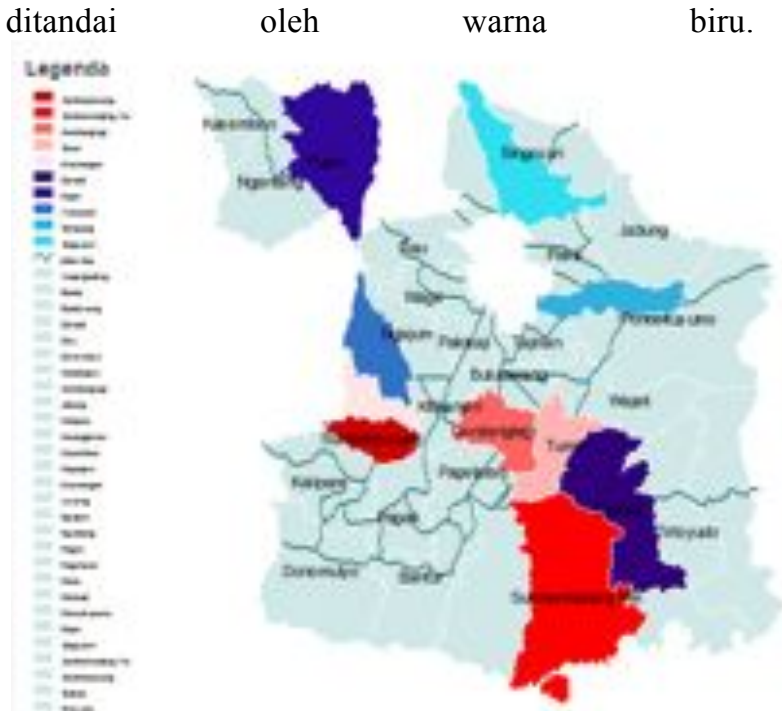

Gambar 3.3Peta hasil proses AHP dengan Warna yang Merepresentasi Tingkat Prioritas Penanggulangan.

Perhitungan yang dilakukan oleh sistem sehingga dapat menghasilkan rekomendasi kecamatan adalah dengan melakukan normalisasi yakni menghitung perolehan nilai kriteria per kecamatan dibagi dengan total atau jumlah seluruh kriteria.

Berikut merupakan contoh data pada alternatif

Kecamatan Sumberpucung:

Jumlah Kasus $=18$

Jumlah Sarana Puskesmas $=9$

Jumlah Lokalisasi $=1$

Jumlah Panti Pijat $=2$

Jumlah Kelompok Penasun $=5$

Jumlah Kelompok TKI/TKW $=685$

\begin{tabular}{|c|c|}
\hline Krilieria & Priscitas lokal \\
\hline Jumlah Kava & $18: 221=0,08: 4$ \\
\hline Jurnlah Sarana punkrmaa & $-157=0.0666$ \\
\hline Jumlah Lokalinasi & $1 / 7=0,1428$ \\
\hline Jumlah Pank Fijat & $252=0,0384$ \\
\hline Junlah belompok Tenasan & $9,91=0,0549$ \\
\hline Jurlah belorepok tKat $1 \mathrm{KW}$ & $685 / 14344=0,0440$ \\
\hline
\end{tabular}

Tabel 2. 6 Prioritas Lokal Alternatif Sumberpucung
Menghitung prioritas global kecamatan Sumberpucungadalah dengan menjumlahkan hasil perkalian prioritas lokal tingkat kriteria dengan prioritas lokal tingkat alternatif sebagai berikut :

$\mathrm{PG}=(0.2857 * 0,0814)+(0,2380 * 0,0656)+$

$(0.1904 * 0,1428)+(0.1428 * 0,0384)+$

$(0.0952 * 0,0549)+(0.0476 * 0,0440)=0,0789$

\section{Kesimpulan dan Saran}

4.1 Kesimpulan

a. Perancangan dan pembangunan sistem pengambilan keputusan dengan metode AHP untuk menentukan lokasi klinik IMS di Kabupaten Malang dapat menjadi rujukan dalam penentuan lokasi klinik IMS.

b. Perancangan dan pembangunan aplikasi sistem pengambilan keputusan dapat divisualisasikan ke dalam Sistem Informasi Geografis berbasis web

\subsection{Saran}

a. Sistem pengambilan keputusan dengan metode AHP untuk menentukan lokasi klinik IMS di Kabupaten Malang dapat dibangun dengan metode lain yang sesuai.

b. Sistem pengambilan yang divisualisasikan ke dalam Sistem Informasi Geografis berbasis web dapat dirancang dengan lebih detail dan memiliki kandungan informasi yang lebih beragam.

\section{Daftar Rujukan}

Arisa Dewi, Yoanita. 2009. Aplikasi GIS untuk Mencari Lokasi Cabang Warung $\mathrm{Bu}$ Kris Baru. Buku Tugas Akhir Jurusan Teknologi Informasi Politeknik Elektronika Negeri Surabaya-Institut Teknologi Sepuluh Nopember. Surabaya.

Prahasta, Eddy. 2007. Membangun Aplikasi Webbased GIS dengan MapServer. Penerbit INFORMATIKA, Bandung.

Prahasta, Eddy. 2009. Tutorial ArcView. Penerbit INFORMATIKA, Bandung.

Prahasta, Eddy. 2012. Tutorial PostgreSQL, PostGIS, dan pgRouting, Penerbit INFORMATIKA. Bandung. 